\title{
CONTEMPORARY ECOLOGY AND AUGUSTINE ON CREATION
}

Fecha de recepción: 29 de octubre de 2018

Fecha de aceptación y versión final: 18 de marzo de 2019

ABSTRACT: Augustine of Hippo, despite his reputation as one of the most important figures in Western theology, is not a popular figure in current theological discussions on ecological issues. This article seeks to know why. It investigates on how some contemporary critics interpret Augustine's doctrines on creation and the Trinity which may have contributed in making Augustine less relevant on issues related to ecology. While it does not directly argue against the possible misreading of Augustine's scheme by some contemporary theologians who have strong ecological concern, it offers an alternative interpretation of Augustine that may shed positive light on classical doctrines which can help promote the so-called «ecological conversion» in the modern times.

KEY WORDS: doctrine; concern; critics; Trinity.

\section{Ecología Contemporánea y Agustín sobre la Creación}

RESUMEN: Agustín de Hipona, a pesar de su reputación como una de las figuras más importantes de la teología occidental, no es una figura popular en las discusiones teológicas actuales sobre temas ecológicos. Este artículo busca saber por qué. Investiga sobre cómo algunos críticos contemporáneos interpretan las doctrinas de Agustín sobre la creación y la Trinidad, que pueden haber contribuido a hacer que Agustín sea menos relevante en temas relacionados con la ecología. Si bien el artículo no discute directamente la posible mala interpretación del esquema de Agustín por parte de algunos teólogos contemporáneos que tienen una gran preocupación ecológica, ofrece una interpretación alternativa de Agustín que puede arrojar luz positiva sobre las doctrinas clásicas que pueden ayudar a promover la llamada «conversión ecológica» en los tiempos modernos.

PALABRAS CLAVE: doctrina; preocupación; crítica; Trinidad.

* Doctorando, Universidad Pontificia Comillas: jaos_marc@yahoo.com 


\section{INTRODUCTION}

"What is happening to our beautiful land?»... so asked the Catholic Bishops' Conference of the Philippines (CBCP) in its pastoral letter published in 1988 as the country faces an unprecedented ecological devastation ${ }^{1}$.

As early as 1988, the Catholic Bishops' Conference of the Philippines, through its pastoral letter, warned that «the attack on the natural world which benefits very few Filipinos is rapidly whittling away at the very base of our living world and endangering its fruitfulness for future generations ${ }^{2}$. The people in this country are living witnesses of the seriousness of climate change, the threat it posed to our ecosystem, and the potential humanitarian crisis it could bring to people in every country.

Thankfully however, the reality of climate change is gradually gaining recognition around the world. More and more people begin to agree that environmental devastation is a serious matter and that steps must be taken to slow it down. And yet, despite this unified effort of world leaders, the solution to the crisis does not seem readily achievable. In fact, even the choice on how to implement the resolutions is open to much disagreement in many countries. Debates over the economic and technological impacts of the proposed solutions to the climate crisis often lead to political impasse which derails the implementation of the conceived solutions. There is no doubt that scientific and technological knowledge, as well as the economic considerations will be key in the actual solutions. However, a closer look into the current ecological dilemma could lead one to suspect that there seem to be more fundamental issues underlying this problem and its roots are much deeper than those that can easily be seen from the scientific, political, social, and the economic level.

Long before the threat of climate change seeped into the social consciousness of civil world leaders, initiatives to jerk consciences on environmental issues had already begun in the heart of the Catholic Church. As early as 1971, Pope Paul VI already raised concern of the «ill-considered exploitation of nature» so that humanity «runs the risk of destroying

1 The Catholic Bishops' Conference of the Philippines, A Pastoral Letter on Ecology: What is happening to our beautiful land (Manila: Catholic Bishops' Conference of the Philippines, 29 January 1988), 1.

2 Ibid. 
it and becoming in turn a victim of its degradation» ${ }^{3}$. John Paul II became increasingly concerned about the issue that in his first Encyclical, he warned about the problem of consumerism and man's failure «to look at natural environment far more than what serves for immediate use and consumption $»^{4}$. He was the first one who calls for the so-called «ecological conversion» ${ }^{5}$. Benedict XVI warned of the evil of relativism and abuse of freedom and pointed out that creation is harmed «where we ourselves have the final word, where everything is simply our property and we used it for ourselves alone» ${ }^{6}$.

In May of 2015, Pope Francis published his second encyclical called Laudato si' with the subtitle «On Care for Our Common Home». It deviated a bit from the conventional dogmatic or spiritual themes, and using some of the latest scientific information available, it focused instead on the ecological concerns that beset humanity in the modern times. Developed around the concept of integral ecology, Laudato si' squares up to the current problem of consumerism and irresponsible development, laments environmental degradation and global warming, and calls all people of the world to take «swift and unified global action» ${ }^{7}$. Pope Francis hinted that the issue on ecological crisis «cannot be approached piecemeal»; it must take into consideration deeper and transcendental questions like "what is the purpose of our life in this world? Why are we here? What is the goal of our work and all our efforts? What need does the earth have of us?» And "unless we struggle with these deeper issues our concern for ecology will not produce significant results» ${ }^{8}$.

Perhaps, more than these existential questions put forward by Pope Francis in Laudato si', there seem to be much deeper metaphysical and even theological roots of the ecological crisis of our time. Behind the many solutions offered by world leaders in the political arena in solving

3 Pope Paul VI, Apostolic letter Octogesims Adveniens, (14 May 1971), 21, Acta Apostolicae Sedis 63 (1971): 416-417.

4 John Paul II, Encyclical Letter Redemptor Hominis, (4 March 1979), 15, Acta Apostolicae Sedis 71 (1979): 287.

5 Cf. John Paul II, Catechesis (17 January 2011), 4: Insegnamenti 41/1 (2011), 179.

6 Benedict XVI, address to the clergy of the Diocese of Bolzano-Bressanone (6 August 208), Acta Apostolicae Sedis 100 (2018): 634.

7 Jim Yardley and Laurie Goodstein, "Pope Francis, in Sweeping Encyclical, Calls for Swift Action on Climate Change", The New York Times (18 June 2015), A6.

8 Pope Francis, Encyclical Letter Laudato si', (4 September 2015), 160, Acta Apostolicae Sedis 107 (2015): 911. 
environmental crisis, are sets of assumptions and preconceived ideas that are often termed as worldviews. The way people evaluate varieties of technical solutions and the moral consideration of their implementation are certainly conditioned by the way they look at the world and reality in general. To influence an outlook of the world is to influence the way people would handle crisis of whatever form and create solutions. And it can be safely said that many worldviews are influenced by some form of philosophical, religious, or even theological convictions. Not surprisingly then even beyond the Catholic religious circle, we find some of the most powerful religious leaders in the world taking the initiative to discuss within their own religious communities current and important ecological issues.

In western theology, one of the most important figures is Augustine of Hippo (354-430). It is general knowledge though that Augustine exercised an enormous influence on the Christian tradition in the Western world that it would seem difficult to understand Western theology itself without somehow making some reference to Augustine. Scholasticism of the middle ages was almost inconceivable apart from his doctrines. Up to the contemporary times, it is almost impossible not to find a reference of him in catechesis, papal encyclicals, or in any important pastoral or theological discourse. To this day, Augustine's writings continue to mold the minds and hearts of many theologians, pastors, and laymen and he is certainly one of the central figures among the Church Fathers who continue to influence modern thoughts and worldviews.

Yet, surprisingly, in current theological discussions on ecological issues, Augustine is not a favorite authority. Among contemporary theologians with strong ecological inclinations, it seems that he is "not a name of good omen», as Rowan Williams observed ${ }^{9}$. In fact, Laudato si', despite its attempt to use and adhere to the Church's traditional doctrine in tackling the current ecological crisis, has not made a single quote or reference to Augustine. This ecological encyclical stands in stark contrast with Pope Benedict's first encyclical entitled: Deus Caritas Est (December 5,2005 ) which bears a great deal of Augustinian citations.

After the publication of Laudato si', many works and studies have been devoted to ecology from different points of view. Yet noticeably, references to Augustine are scarce and often used only as a pretext to deal

9 Rowan Williams, On Augustine (New York: Bloomsbury Publishing, 2016), 60. 
with other issues related to environment or ecology ${ }^{10}$. It seems that some contemporary critics of Augustine who viewed him to have Platonic orientation and prioritizing Greek philosophy over Scriptures may have a role in this situation. Apparently, a large contingent of modern scholars would view Augustine's doctrine on creation in a negative light.

This article investigates on how some contemporary critics interpret Augustine's doctrines on creation and the Trinity which may have contributed in pushing Augustine to the gutters on issues related to ecology. While it does not directly argue against the possible misreading of $\mathrm{Au}-$ gustine's scheme by some contemporary theologians who have strong ecological concern, it offers an alternative interpretation of Augustine's doctrine that may shed positive light on classical doctrines which can help promote the so-called «ecological conversion» in the modern times.

\section{CONTEMPORARY CRITICS OF AUGUSTINE}

Needless to say, when Augustine wrote his reflections on creation and the Trinity, he did not have the contemporary ecological concerns as we have known them today, so that a straightforward accusation that he created theological problems on current ecological issues is absurd. But some contemporary critics have blamed Augustine's doctrine of creation and the Trinity to have laid the ground for doubt towards the goodness of materiality that may have contributed a great deal to the ecological mess in which this planet now lives. Furthermore, Augustine is accused of forming a model of Trinity that fails to offer good news to ecology. The «gravity» of Augustine's teaching seems to be such that for Colin Gunton, one of the major challenges that faces a theology of creation in the modern West, is «to overcome the influence of Augustine» and to embrace a

10 Cf. J. Lyndon, Joaquín García y Roberto Jaramillo, Ecoteología. Una perspectiva desde San Agustín. Actas del IV Simposio sobre la relectura del pensamiento de San Agustín desde América Latina. Sâo Paulo, 23-28 de enero 1995 (México: OALA, 1996). M. E. Sacchi, "Ecología y cristianismo", Ars Brevis 4 (1998): 247-270. As its title denotes, this article is a general study which does not really delve into the details of the Augustinian thought. In this rather generic article, Augustine is cited only for the purpose of endorsing a doctrine of the Catholic Church indicating that the world was created from nothing by a Triune God. It does not, in anyway, present a structured reflection on the Augustinian thought related to ecology; instead the authors used the Augustinian doctrine to back up various points of the Church's doctrine on creation, rather than on ecology. 
doctrine of creation that is cut off from his impoverish Trinity ${ }^{11}$. So what are exactly those doctrines of Augustine that his critics perceive to have cast a dark cloud on the contemporary ecological discourse? ${ }^{12}$.

\subsection{The Problem of Dualism}

One of the Augustinian thesis on creation perceive by some contemporary critics as disturbing and problematic is Augustine's emphasis on the radical distinction between God and the created universe. Moreover, in the realm of creatures, there is a hierarchy of perfections, with the spiritual realities being superior and possessing an imposing authority over the material. This view is exemplified by Sallie McFague when she writes:

«The received view consisted of a nest of shared beliefs, but the two most important for our concern are the God created 'ex nihilo', from 'nothing', and that God created hierarchically, with the physical subordinated to the spiritual [...]. The imaginative picture it paints is of a God fashioning the world, either intellectually by word [...] or aesthetically by craft [...] but in either case out of what is totally different from God, and in a manner that places humanity above nature, spirit above body» ${ }^{13}$.

As to the theme that the more perfect tends to lord over the less perfect, Anne Primavesi writes:

«A particular reading of this foundational text (Gn 1-3) has given Western culture the fundamental idea that the universe is a hierarchy: a system of order imposed by spiritual power from above [...]. Whenever we affirm belief in God as "Maker of the Universe" we are referring to this image and reinforcing the claim to have and to exercise "spiritual power" over matter» ${ }^{14}$.

11 Cf. Colin Gunton, "Between Allegory and Myth: The Legacy of the Spiritualizing of Genesis" in The Doctrine of Creation, ed. Colin Gunton (Edinburgh: T. and T. Clark, 1997), 47-62. Also cf. Colin Gunton, Promise of Trinitarian Theology (Edinburgh: T. and T. Clark, 1991), 32.

12 In looking at the contemporary critiques of Augustine, much focus is directed to modern English writers and especially to Colin Gunton's assessment of Augustine's doctrine of the Trinity, as the latter had more serious engagement with what is "understood» as Augustine's doctrinal legacy.

13 Sallie McFague, Models of God: Theology for an Ecological Nuclear Age (London: SCM, 1987), 109.

14 Anne Primavesi, From Apocalypse to Genesis: Ecology, Feminism and Christianity (London: Burns \& Oates, 1991), 203. 
The authors quoted above are women theologians with strong ecological leaning. The "problematic dualism» that is being referred to, is the radical and seeming "unbridgeable gap» between God and the world, the spiritual and the material, which seems to be Augustine's characteristic insights when he deals with the relationship between God and the created world. In their reading of Augustine, the Creator is absolutely alien from the world He created, and creation itself is an act of God imposing spiritual shape or form upon an intrinsically formless or worthless matter. The whole creative process involves an obvious discontinuity between a God who is absolute and pure spirit, and the created universe which is contingent and material.

The critics of Augustine who tend towards this direction have become impatient with the classical doctrine which they perceive to bear an Augustinian hallmark and they want to remove from the discourse of creation any element of «dualism» that lays the grounds or sanctions other subsequent «dualisms»: mind and body, humanity and nature, man and woman, etc. They argued that focusing on the basic distinction between cause and effect, active and passive, and allot a heavy metaphysical and theological importance to the former, will create an attitude which looks up to the spiritual realities as model worthy of emulation but despises creation and its material components or reduce them to mere tool for a much nobler spiritual end. In this line of thinking, man must not worry so much about his own corporeal conditions nor the physical environment around him because his fundamental vocation must be oriented towards the wellbeing of his spiritual soul. Such an attitude will have disastrous impact on how we deal with our ecological environment. They propose that the present ecological crisis demands new models of creation discourse and argue passionately on the imagery of a God «embodied» in the creation or better still, a God who "gives birth» to creation which is «bound in» with God's own being ${ }^{15}$.

15 It is difficult to construct a coherent perspective that unites the modern critics of Augustine. What is being described above are just few of the pertinacious arguments put forward by the authors being cited. Other authors who tend towards this direction are Elaine Pagels, Adam, Eve and the Serpent (London: Penguin Books, 1988). Rosemary Radford Ruether, Gaia and God: An Ecofeminist Theology of Earth Healing (San Francisco, CA: Harper Collins, 1992), 9. A more serious engagement with what is "understood» as Augustine's doctrinal legacy can be found in Colin Gunton's work, "Augustine, the Trinity and the Theological Crisis of the West", Scottish 


\subsection{Neoplatonic Orientation}

Colin Gunton traces the problem of Augustine's dualism to the latter's Neoplatonist philosophical position ${ }^{16}$. Augustine's «sophisticated but more Platonizing approaches» shows his commitment to Greek philosophy over and against the scriptural portrayal of God at work in creation ${ }^{17}$. In his interpretation of Augustine, creation is twofold: the creation of the Platonic «intellectual» world of forms and the physical world which is patterned after the eternal forms ${ }^{18}$. This dualistic scheme leads to a «distorted» appreciation of creation where a hierarchy of value is set up: the immaterial or spiritual is perceived to be higher than, and must be favored over, the material creation which is inferior than the immaterial creation.

This Platonic approach, however, has undesirable effects. First, is the growing dislike of the material order of things in favor of the immaterial mind that is derived from the Platonic forms. It develops an attitude which tends to overlook the inherent goodness and beauty of concrete material realities as they are only valued in relation to the immaterial and eternal beauty. "Material beauty, which the Augustinian tradition regards as of importance only as the route to a higher, immaterial beauty... is necessarily linked with plurality, with the multiplicity of created reality ${ }^{19}$. This diverse particularity of creatures however is disdained as leading the mind away from the contemplation of the immaterial and immutable One ${ }^{20}$. Obviously, it is incompatible with scriptural account which acknowledges the goodness of every creature as they exist as concrete, particular beings in the world.

In Augustine's effort to undermine God's direct involvement in the creation of material realities, he favors the description of the one God who creates by arbitrary will. God is essentially a divine will totally

Journal of Theology 43 (1992): 33-58, and The One, the Three and the Many: God, Creation and the Culture of Modernity (Cambridge: Cambridge University Press, 1993).

${ }_{16}$ Cf. Colin Gunton, The One, the Three and the Many: God, Creation and the Culture of Modernity (Cambridge: Cambridge University Press, 1993), 2.

17 Ibid., 2-3, 54-56.

18 Colin Gunton, Triune Creator: A Historical and Systematic Study (Grand Rapids, MI: Eerdmans, 1998), 2.

19 Colin Gunton, The One, the Three and the Many, 140.

20 Ibid., 2-3, 54-56. 
distinct and separated from the material creation. The Neoplatonic conception of Angels are the first created forms and through them all other creatures are made. As Gunton puts it:

«Augustine's interpretation of Genesis 1 in terms of a creation of forms, eternal archetypes, turns the celebration of particularity and variety into something dangerously like its subversion, because the replacing of Christology by Platonic universals generates a very different conception of the relation of universal and particular. Not the particularizing will of God, but the general conceptual forms come into the center ${ }^{21}$.

The result is an insurmountable gap between the creator and the creatures. And among the creatures of God a higher value is placed upon spiritual and intellectual creatures because they are by nature closer to God.

This Platonic scheme of Augustine can also stand in the way of the progress of natural sciences. Science gains knowledge through empirical observation of changing things. Platonic approach has the problem of linking material creatures to timeless and unchanging forms. Subsequent Western theology, influenced by this Platonic orientation, is unable to reconcile with theories of evolution, which is based on the observation of contingent realities ${ }^{22}$. Resistance to evolutionary theory is the result of devaluing things that are subject to change. In fact, for Augustine, change and temporality itself is "fallenness» and disorder, instead of human sinfulness «whose redemption is the hope of the Christian Gospel»"23.

\subsection{TRINITY AND Modalism}

Colin Gunton stresses the relationship between a well-formulated doctrine of creation and the perception of God as Trinity. In Gunton's view, the strong Platonic orientation of Augustine has led him to completely misunderstand the Trinitarian doctrine developed by Irenaeus and later by the Cappadocians that was based on the scriptural revelation of God's creative activity through the Son and the Spirit. Augustine

\footnotetext{
21 Ibid., 55-56.

22 Ibid., $2-3$.

23 Ibid., 83.
} 
uses instead the Greek philosophical theology which focuses on the universal forms as its point of departure. Thomas Marsh shares a similar interpretation when he writes: «But where that (Eastern) tradition would have maintained strong sense of the divine monarchy [...] Augustine abandons this position and understands the one God to mean the one divine substance or nature which then is verified in the Father, Son, and Holy Spirit» ${ }^{24}$.

Gunton observes that instead of developing a Trinitarian doctrine based on the reflection of God's redemptive work in Jesus's life, death, and resurrection and the Holy Spirit's outpouring on the first Christians, Augustine uses the Platonic doctrine of knowledge, envisioning God as some sort of «super-mind $»^{25}$. In this theological framework, the Trinity is reduced to a process of the mind, and favors analogies of the Trinity that are associated with the intellectual activity of the immaterial soul. This is the reason why Augustine did not look for analogies of the Trinity in the material world, instead looked for vestiges of the Trinity in human mind. Eventually, this has led Augustine to fall into a trap which reduces the three divine persons to the overarching mind of which they are merely processes ${ }^{26}$. The result is modalism: "The only conclusion can be that, in some sense or another, it is divine substance and not the Father that is the basis of the being of God, and therefore, a fortiori, of everything else ${ }^{27}$.

Gunton notes also that Augustine's dislike of anything related to materiality prevents him from taking seriously the Incarnation of Christ as a basis for knowing the Son and the Son's relationship to $\operatorname{God}^{28}$. His attempts to formulate the doctrine of Trinity are not grounded in the humanity of Jesus but in the divinity of the Son, thus generating an abstract vision of the Trinity as nothing more than a «rational triad $»^{29}$. When the Word Incarnate is no longer uniquely identified as the mediator, the relationship of the Word to the Fa-

\footnotetext{
24 Thomas Marsh, The Triune God (New London, CT: Twenty-third Publications, 1994), 132.

25 Colin Gunton, The One, the Three and the Many, 44.

26 Ibid., 44-45.

27 Cf. Colin Gunton, Promise of Trinitarian Theology (Edinburgh: T. and T. Clark, 1991), 54.

28 Ibid., 33-34.

29 Ibid., 34-35.
} 
ther and the Holy Spirit becomes abstract and «flattened out», so that the trinitarian relations become meaningless over and against the oneness of God's substance.

In Gunton's view, the influence of Greek Philosophy inhibits Augustine from adopting the Cappadocians' notion of God's ousia which was conceived from the reflection based on the dynamic relationships of the three persons as described in Scripture. The Cappadocians conceived the three persons or hypostases not at as three individuals but three «concrete particulars in relation to one another» ${ }^{30}$. In this dynamic relationship, the three persons together constitute one substance or ousia. Gunton argued that Augustine could not simply grasp the relationship between ousia and hypostases as both distinct and mutually integrative. The reason is that Augustine opts for a static, unchanging conception of ousia which made it difficult for him to integrate the concept of persons because its dynamism and adherence to the former would contradict "Aristotelian subject-predicate $\operatorname{logic} »^{31}$. Hence, in relation to ousia, hypostasis cannot be an «ontological predicate» but only a «logical predicate». In this theological framework, however, the three hypostases «disappear into the all-embracing oneness of God ${ }^{32}$. Gunton concludes that Augustine has a modalistic tendency ${ }^{33}$.

Regarding creation, Augustine's lack of concern for God's economic work has led him to reduce creation as mere object of God's «arbitrary will». This minimizes God's personal involvement through the works of the Son and the Holy Spirit ${ }^{34}$. This lack of trinitarian involvement in the creation also has repercussion in God's redemptive activity so that in Augustine, the link between creation and redemption is "weakened to the point of disappearing» ${ }^{35}$. The oneness of God is "manifestly elevated over the plurality of the Trinity». In the end, Gunton concludes that Augustine is not trinitarian in his doctrine of creation but monistic ${ }^{36}$.

\footnotetext{
30 Ibid., 39.

31 Ibid., 39-41.

32 Ibid., 42.

33 Ibid., 53.

34 Cf. Colin Gunton, One, the Three and the Many, 189-90.

35 Ibid., 120.

36 Ibid., 205.
} 


\section{AUGUSTINE ON TRINITY AND CREATION}

At this point, we try to turn to Augustine's own arguments and offer an alternative assessment on issues stressed by some of his critics ${ }^{37}$.

\subsection{SCRIPTURES, TRADition, AND REAson}

The assumption that Augustine's training in skepticism and Neoplatonism and his general Platonic philosophical approach would have a profound effect upon his theology, could probably color how one interprets Augustine's arguments. But while the influence of philosophical thoughts in Augustine cannot be denied, some scholars observe that after his conversion to Christianity, no philosophical school can take pride of having a dominant influence ${ }^{38}$. All of Augustine's arguments were subjected to the critique of scriptural faith. John M. Rist observes that contrary to the assumption that Augustine simply downplayed the theological-biblical traditions of the church in favor of a philosophical method, it is more plausible that Augustine maintained a more balance

37 While it is impossible to incorporate in this article an exhaustive citations and arguments of Augustine, we attempt to emphasize a few citations and point out that there may be a misreading of Augustine's scheme by some contemporary theologians. A more exhaustive presentation is made by Scott A. Dunham in his book, The Trinity and Creation in Augustine (Albany: State University of New York Press, 2018). Cf. Cándido Tejerina, "Creación y caída en los libros XI-XIV de 'La ciudad de Dios”, Estudio Agustiniano 5 (1970): 239-296; Marceliano Arranz Rodrigo, "Fuentes de la doctrina agustiniana de la creación virtual", Estudio Agustiniano 23 (1988): 153-166; Ídem, "Interpretación agustiniana del relato genesíaco de la creación", en San Agustín. Meditación de un Centenario, coord. José Oroz Reta (Salamanca: Ed. Universidad Pontificia de Salamanca, 1987), 47-56; Ídem, "Semillas de futuro. Anotaciones a la teoría agustiniana de la creación virtual”, Cuadernos Salmantinos de Filosofía 23 (1987): 43-77; Ídem, "Semillas de futuro. Anotaciones a la teoría agustiniana de la creación virtual”, Cuadernos Salmantinos de Filosofía 13 (1986): 35-60; Ídem, "Semillas de futuro. Aportes agustinianos a la teoría de la creación virtual”, en San Agustín, un hombre para hoy, vol. 2. Congreso Agustiniano de Teología. 26-28 de agosto de 2004, coord. José Demetrio Jiménez (Buenos Aires: Religión y Cultura, 2006), 93-112.

38 Augustine himself acknowledged the influence of several philosophical writers including Cicero and Plotinus in the Confessions where he describes his journey to conversion. 
understanding of the relationship of philosophy and faith, with each accorded its proper place ${ }^{39}$.

Scott Dunham noted Augustine's commitment «to exploring Trinitarian faith using the received tradition of Nicaea, as well as the necessity of grounding such an exploration in the biblical revelation of God's identity ${ }^{40}$. Augustine himself seemed to have outlined his preferred approach when he presented The Trinity as an answer to the "talkative arguers» (garrulis ratiocinatoribus) who doubt the Catholic doctrine:

«First, however, we must demonstrate, according to the authority of the Holy Scriptures, whether the faith be so (that God is a Trinity). Then, if God be willing and aid us, we may perhaps at least so far serve these talkative arguers (garrulis ratiocinatoribus) [...] as to enable them to find something which they are not able to doubt $[\ldots]\rangle^{41}$.

Here, Augustine shows that his starting point in explaining and proving the doctrine of the triune nature of God to the "talkative arguers» (garrulis ratiocinatoribus) so as "to enable them to find something which they are not able to doubt» is the Holy Scripture. In the Literal Meaning of Genesis, Augustine indicates his firm belief on the authority of the Sacred Scriptures over "false Philosophy» and the «superstition of false religion»:

«But when they (philosophers) produce from any of their books a theory contrary to our Scripture, and therefore contrary to the Catholic faith, either we shall have some ability to demonstrate that it is absolutely false, or at least we ourselves will hold it so without any shadow of a doubt. And we will so cling to our Mediator... that we will

39 Cf. John M. Rist, Augustine: Ancient Thought Baptized (Cambridge: Cambridge University Press, 1994), 5-10.

40 Scott A. Dunham, The Trinity and Creation in Augustine (Albany: State University of New York Press, 2018), 26.

${ }_{41}$ Augustine, Trin. 1, 2, 4, trans. Arthur West Haddan, in Nicene and Post-Nicene Fathers, First Series, vol. 3, ed. Philip Schaff (Buffalo, NY: Christian Literature Publishing Co., 1887). PL 42, 822: «Sed primum secundum auctoritatem Scripturarum sanctarum utrum ita se fides habeat demonstrandum est. Deinde si voluerit et adiuverit Deus, istis garrulis ratiocinatoribus, elatioribus quam capacioribus atque ideo morbo periculosiore laborantibus, sic fortasse serviemus ut inveniant aliquid unde dubitare non possint, et ob hoc in eo quod invenire nequiverint, de suis mentibus potius quam de ipsa veritate vel de nostris disputationibus conquerantur». 
not be led astray by the glib talk of false philosophy or frightened by the superstition of false religion ${ }^{42}$.

A forthright reflection on this Augustinian text can lead one to see that rather than making abstract philosophical concepts his point of departure in the formulation of Trinitarian doctrine, Augustine's approach is to set the foundations provided by biblical faith at the heart of his response against those who doubted the Catholic doctrine or sought rational models and theories to explain God's Threeness ${ }^{43}$.

Moreover, some scholars observe that the emphasis that Augustine places upon the scriptural basis for the doctrine of the Trinity does not compromise the rational explanation of the doctrine ${ }^{44}$. Scripture and right reason are inseparable in Augustine because they complement each other. Philosophy which is committed to right thinking does not necessarily contradict theological explanation. In fact, it provides theology and faith sound rational foundations. Likewise, the revelation and explanation of faith enlighten reason so that it can conceive truths which otherwise it can never achieve without the aid of biblical revelation like the mysteries of the Trinity and the incarnation of Christ.

The Sacred Tradition of the Church also plays a very important part in Augustine's Trinitarian doctrine. After the quotation (from trin. 1, 4) we mentioned above, Augustine continues his explanation of what he understands as the purpose of the "Catholic expounders of the divine Scriptures» (catholici tractatores):

"Yet not that this Trinity was born of the Virgin Mary, and crucified under Pontius Pilate, and buried, and rose again the third day, and ascended into heaven, but only the Son. Nor, again, that this Trinity

42 Augustine, Gn. litt. inp. 1, 21, 41, trans. J. H. Taylor, S.J., (Newman Press, New York, 1982). PL 34, 262: «Quidquid autem de quibuslibet suis voluminibus his nostris Litteris, id est catholicae fidei contrarium protulerint, aut aliqua etiam facultate ostendamus, aut nulla dubitatione credamus esse falsissimum: atque ita teneamus Mediatorem nostrum, in quo sunt omnes thesauri sapientiae atque scientiae absconditi (Col. 2,3), ut neque falsae philosophiae loquacitate seducamur, neque falsae religionis superstitione terreamur».

43 This interpretation of the Augustinian approach contradicts Gunton's view which emphasizes on Augustine's commitment to Greek philosophy over and against the scriptural portrayal of God.

44 Cf. Muller E., “The Dynamic of Augustine's De Trinitate: A Response to a Recent Characterization”, Augustinian Studies 26 (1995): 65-91. 
descended in the form of a dove upon Jesus when He was baptized; nor that, on the day of Pentecost, after the ascension of the Lord, when there came a sound from heaven, as of a rushing mighty wind, the same Trinity sat upon each of them with cloven tongues like as of fire, but only the Holy Spirit. Nor yet that this Trinity said from heaven, You are my Son, whether when He was baptized by John, or when the three disciples were with Him in the mount, or when the voice sounded, saying, I have both glorified it, and will glorify it again; but that it was a word of the Father only, spoken to the Son; although the Father, and the Son, and the Holy Spirit, as they are indivisible, so work indivisibly. This is also my faith, since it is the Catholic faith ${ }^{45}$.

Augustine subjected his understanding of the triune God within the Nicene tradition by giving a straightforward quotation of the creed in the first lines of this quotation and annexed his own explanation of its trinitarian significance. He also cites specific scriptural events where each of the three divine persons are revealed and associated with the particular action.

Clearly the citation above shows that for Augustine, the problem of the Triune Being is not merely about defending the unity of the divine substance. By citing the Scripture and the Nicene creed, he shows that specifically, the problem of the Trinity is about understanding how the threeness of the persons is both particular (as revealed in Scriptures) and inseparable. The real challenge for Augustine is to explain how the three distinct divine persons are one substance in a way that also affirms the specific works of the Father, Son, and Holy Spirit in the trinitarian

45 Augustine, Trin. 1, 4, 7. trans. Arthur West Haddan, in Nicene and PostNicene Fathers, First Series, vol. 3, ed. Philip Schaff (Buffalo, NY: Christian Literature Publishing Co., 1887). PL 42, 824: «Non tamen eamdem Trinitatem natam de virgine Maria et sub Pontio Pilato crucifixam et sepultam tertio die resurrexisse et in caelum ascendisse, sed tantummodo Filium. Nec eamdem Trinitatem descendisse in specie columbae super Iesum baptizatum, aut die Pentecostes post ascensionem Domini sonitu facto de caelo quasi ferretur flatus vehemens et linguis divisis velut ignis sedisse super unumquemque eorum, sed tantummodo Spiritum Sanctum. Nec eamdem Trinitatem dixisse de caelo: Tu es Filius meus, sive cum baptizatus est a Iohanne sive in monte quando cum illo erant tres discipuli, aut quando sonuit vox dicens: Et clarificavi et iterum clarificabo, sed tantummodo Patris vocem fuisse ad Filium factam quamvis Pater et Filius et Spiritus Sanctus sicut inseparabiles sunt, ita inseparabiliter operentur. Haec et mea fides est, quando haec est catholica fides». 
economy as portrayed in the scripture and summarized in the Nicene Creed.

Keeping in mind Augustine's chosen method in addressing the problem of the Trinity - that is, a careful consideration of scriptural texts and the humble submission to tradition while not undermining critical reason - we now turn to his defense of the trinitarian doctrine.

\subsection{God is a Trinity, But Not Triple}

We have already seen above how some «modern critics» of Augustine have labelled him to have some modalistic tendencies. Robert Jenson further emphasized such modalistic tendency in Augustine in this manner:

«The three persons are not only equally related to the one substance, but identically related, so that the difference between them, that is, the relations, are irrelevant to their God... When the Nicenes called the Trinity as such God, they so named him because of the triune relations and differences; when Augustine calls the Trinity as such God, it is in spite of them $»^{46}$.

Jenson points out that because of the idea of a simple divine substance, Augustine sees simply in the threeness of God a logical problem, but he does not consider the persons to be ontologically distinct in the Godhead. But then Augustine wants to avoid exactly this kind of misunderstanding whereby one imagines an underlying substance, either distinct from the three persons or ontologically more real than the divine relations of the persons. Augustine writes:

«Since, therefore, the Father alone, or the Son alone, or the Holy Spirit alone, is as great as is the Father and the Son and the Holy Spirit together, in no manner is $\mathrm{He}$ to be called threefold ${ }^{47}$.

46 Robert Jenson, The Triune Identity (Philadelphia: Fortress Press, 1982),118-119.

47 Augustine, Trin. 6, 8, 9. trans. Arthur West Haddan, in Nicene and Post-Nicene Fathers, First Series, vol. 3, ed. Philip Schaff (Buffalo, NY: Christian Literature Publishing Co., 1887). PL 42, 929: "Cum itaque tantus est solus Pater, vel solus Filius, vel solus Spiritus Sanctus, quantus est simul Pater et Filius et Spiritus Sanctus, nullo modo triplex dicendus est». 
This in-depth understanding of equality of persons is precisely what enables Augustine to avoid a modalistic conception of the Trinity, since the equality of the persons is such that neither the idea of difference of substance between any of the three, nor the idea that the divine substance can exists apart from the three, can be thought of:

«In God Himself, therefore when the equal Son, or the Holy Spirit equal to the Father and the Son, is joined to the equal Father, God does not become greater than each of them severally; because that perfectness cannot increase. But whether it be the Father, or the Son, or the Holy Spirit, He is perfect, and God the Father the Son and the Holy Spirit is perfect; and therefore He is a Trinity rather than triple» ${ }^{48}$.

When Augustine speaks of the equality of each person with the other and with the whole, it is not because he understands the Trinity to be a substance without distinction between the persons, but because the idea of the divine simplicity enables him to conceive of the three persons as each having being in himself perfectly and equally. Despite their distinction, their union does not increase the perfection of the Godhead, because His fullness of perfection is so that nothing can be added nor be subtracted from it.

Clearly, Augustine sets out to explain the doctrine in the light of the scriptural presentation of the divine missions citing scriptural events where each of the three divine persons are explicitly associated with particular action. For Augustine, the three persons we profess in the creed are indeed the one God of the scripture, but not in such a way that the three became incarnate in Jesus, but Jesus alone; nor were the three all manifest in the dove at Christ's baptism, but the Spirit alone; nor the three who addressed the Son at his baptism and at the transfiguration, but the Father alone ${ }^{49}$. Hence, based on this scriptural account, the equality of the persons with each other and with the Trinity as whole does not mean that the persons are «flattened out into an indistinct substance», as some critics of Augustine would suggest ${ }^{50}$. The one substance is the Father, Son, and Holy Spirit who are each in themselves what the others are, without being the others, and are one trinitarian God but not triple.
48 Ibid.
49 Cf. Augustine, trin. 1, 7.
50 Cf. Colin Gunton, Promise of Trinitarian Theology, 54. 


\subsection{Creation, the Work of the Triune God}

Consistent to his theological scheme of founding his doctrine of the Trinity upon specific scriptural account, Augustine also has founded his doctrine of creation upon the divine activity as revealed in the scripture. And just as for Augustine the biblical account reveals the reality of the Triune God, so the biblical record of God's redemptive work will also manifest the Triune nature of God's activity in creation for it is the same God who is shown in the scripture as both creator and redeemer ${ }^{51}$. In a particularly condensed passage in Book 1 of The Literal Meaning of Genesis, Augustine lays out his view on why the act of creation is triune in character:

«Hence, in the very beginning of creation [...] it is the Blessed Trinity that is represented resented as creating. For, when Scripture says, In the beginning God created heaven and earth, by the name of "God" we understand stand the Father, and by the name of "Beginning", the Son, who is the Beginning, not for the Father, but first and foremost for the spiritual beings He has created and then also for all creatures; and when Scripture says, And the Spirit of God was stirring above the water (Gn 1,2), we recognize a complete enumeration of the Trinity. So in the conversion and in the perfecting of creatures by which their species are separated in due order, the Blessed Trinity is likewise represented: the Word and the Father of the Word, as indicated in the statement, God said; and then the Divine Goodness, by which God finds pleasure in all the limited perfections of His creatures, which please Him, as indicated by the words, God saw that it was good $»^{52}$.

51 In his book Colin Gunton and the Failure of Augustine. The theology of Colin Gunton in the Light of Augustine (Pickwick Publications, Oregon 2011), Bradley G. Green exposes the deficiency of Gunton's reading of Augustine. Green argues that Augustine did not break the link between creation and redemption but affirmed that the created order of the universe is a means for achieving genuine knowledge of God. Moreover, the «created order» is the only means by which redemption can be realized.

52 Augustine, Gn. litt. 1, 6, 12, trans. John Hammond Taylor: Ancient Christian Writers. Kindle Locations 277-281, (Kindle Edition). PL 34, 250-1: «Ut quemadmodum in ipso exordio inchoatae creaturae, quae coeli et terrae nomine, propter id quod de illa perficiendum erat, commemorata est, Trinitas insinuatur Creatoris (nam dicente Scriptura: In principio fecit Deus coelum et terram [Gn 1,1]; intellegimus Patrem in Dei nomine, et Filium in principii nomine, qui non Patri, sed per seipsum creatae primitus ac potissimum spiritali creaturae, et consequenter etiam universae creaturae principium est: dicente autem Scriptura: Et Spiritus Dei ferebatur super aquam [Gn 1,2], completam commemorationem Trinitatis agnoscimus); ita et in 
In the quotation above, «God» refers to the Father in Augustine's language of trinitarian doctrine. The Father who is the source of the Son in the sense that the Son is always from the Father, and the Holy Spirit is from the Father primarily and through the $\operatorname{Son}^{53}$, is also the source of creation. But unlike the divine persons who are coeternal and equal with the father, the creation is made from nothing and is therefore different and not equal to the Father.

The phrase «in the beginning» refers to the Son. This ascription to the Son by Augustine is not evident in Genesis but he finds justification in the Johannine prologue wherein John claims that in the beginning everything is created through the Word. Augustine notes that according to John, everything is created through the divine Word of God, who is the coeternal Son of the Father but was himself uncreated ${ }^{54}$. In the Book 1 of The Literal Meaning of Genesis, he said:

"And does this belong to the Divine Word... In the beginning was the Word, and the Word was with God, and the Word was God (Jn 1,1)? When it is said of the Word, All things have been made through Him (Jn 1,3), it becomes quite clear that light was made through Him when God said, Let there be light (Gn 1,3), and so this utterance of God is eternal. For the Word of God, true God in the bosom of God and the only Son of God, is coeternal eternal with the Father; and yet through this utterance of God in the eternal Word, creation has been brought about in time ${ }^{55}$.

Similarly, in the work of conversion, Augustine suggests the involvement of the Father and the Son by explaining the phrase «God said» as

conversione atque perfectione creaturae, ut rerum species digerantur, eadem Trinitas insinuetur: Verbum Dei scilicet, et Verbi generator, cum dicitur: Dixit Deus; et sancta bonitas, in qua Deo placet quidquid ei pro suae naturae modulo perfectum placet, cum dicitur: Vidit Deus quia bonum est (Gn 1,3)».

53 Cf. Scott Dunham, The Trinity and Creation in Augustine, 37-40.

54 Cf. Jn 1,18.

55 Augustine, Gn. litt. 1, 2, 6, trans. John Hammond Taylor: Ancient Christian Writers. Kindle Locations 277-281, (Kindle Edition). PL 34, 218: «Et utrum hoc ipsum ad naturam pertineat Verbi eius, de quo dicitur: In principio erat Verbum, et Verbum erat apud Deum, et Deus erat Verbum (Jn 1,1)? Cum enim de illo dicitur: Omnia per ipsum facta sunt (Jn 1,3); satis ostenditur et lux per ipsum facta, cum dixit Deus: Fiat lux (Gn 1,3). Quod si ita est, aeternum est quod dixit Deus: Fiat lux; quia Verbum Dei Deus apud Deum, Filius unicus Dei, Patri coaeternus est: quamvis Deo hoc in aeterno Verbo dicente creatura temporalis facta sit». 
referring to "the Word» and the «Father of the Word». What is «said» is the Word and it is the Father who «speaks» in eternity.

Augustine understands the quotation from Genesis «and the Spirit of God was stirring above the water ${ }^{56}$ as referring to the Holy Spirit when he notes that by this phrase «we recognize a complete enumeration of the Trinity». But when referring to the work of the conversion and in the perfecting of creatures, Augustine goes further by identifying the Holy Spirit with God's love and «goodness by which God finds pleasure in all the limited perfections of His creatures». The Holy Spirit works to perfect creaturely love which Augustine describes as «needy and poor»:

«Now, love is generally needy and poor, so that its outpouring makes it subordinate to the objects that it loves. Hence, when there is mention of the Spirit of God, whereby the Divine Goodness and Love are to be understood, perhaps He is said to be stirring above creation, so that God may be thought of as loving the work to be produced not out of any need or necessity, but solely out of the largeness of His bounty (abundantiam beneficentiae)» ${ }^{57}$.

In here, Augustine describes the Holy Spirit as goodness and love «stirring above the water» (Gn 1,2) in the light of the divine unconditional and self-sufficient love that is poured out or given «out of the largeness of God's bounty» (abundantiam beneficentiae). In contrast to creaturely love which is subordinated to the object of its love, God's love is not needy, not subordinated to anything else, but overflows freely from its inner bounty.

When Augustine identifies the working of the three persons in the act of creation, it is not a sheer exercise of theological speculation, testing his trinitarian theory on an obscure biblical text. Rather, Augustine himself is convinced of the necessity of the trinitarian doctrine he received from the Church that he believes that God's activity revealed in scripture must always be triune in nature.

\footnotetext{
56 Cf. Gn 1:2.

57 Augustine, Gn. litt. 1, 7, 13, trans. John Hammond Taylor: Ancient Christian Writers. Kindle Locations 277-281, (Kindle Edition). PL 34, 251: «An quoniam egenus atque indigus amor ita diligit, ut rebus quas diligit, subiciatur; propterea cum commemoraretur Spiritus Dei, in quo sancta eius benevolentia dilectioque intellegitur, superferri dictus est, ne facienda opera sua per indigentiae necessitatem potius quam per abundantiam beneficentiae Deus amare putaretur».
} 


\subsection{The Vestiges of Trinity in Creation}

Contrary to Gunton's claim that Augustine did not look for analogies of the Trinity in the material world but solely in the immaterial activity of the human mind ${ }^{58}$, Augustine implies vestiges of the Trinity even in material creatures. This is because for Augustine, the entire universe bears the mark of the creator and somehow reflects His nature. Taking an important hint from the Book of Wisdom, Augustine claims that all of creation participates in the divine being through measure, number, and weight $t^{59}$. Augustine makes a connection between «six days of creation» and the threefold ordering of creation because both indicate the perfections of creatures that originated from and governed by the Trinity. Reflecting on Wisdom 11:20, Augustine said:

«We should call to mind what Scripture says elsewhere: «Thou hast ordered all things in measure and number and weight». And let the soul that is able reflect on this [...] and let it consider whether these three - measure, number, and weight - in which, according to Scripture, God ordered all things, existed somewhere before the creation of every creature, or whether they too were created [...]. Before creation nothing existed except the Creator. Therefore, these three were in Him. But how? The works of creation are, so Scripture tells us, in Him. Shall we in some way identify measure, number, and weight with Him, and say that the works of creation are, as it were, in Him by whom they are ruled and governed? ${ }^{60}$.

58 Cf. Colin Gunton, The One, the Three and the Many, 44-45.

59 The Latin words Augustine used were mensura, numerus, and pondus.

60 Augustine, Gn. litt. 4, 3, 7, trans. John Hammond Taylor: Ancient Christian Writers. Kindle Locations 277-281, (Kindle Edition). PL 34, 299: «Quapropter cum eum legimus sex diebus omnia perfecisse, et senarium numerum considerantes, invenimus esse perfectum, atque ita creaturarum ordinem currere, ut etiam ipsarum partium, quibus iste numerus perficitur, appareat quasi gradata distinctio; veniat etiam illud in mentem, quod alio loco Scripturarum ei dicitur: Omnia in mensura, et numero, et pondere disposuisti (Sap 11, 21); atque ita cogitet anima, quae potest, invocato in auxilium Deo, et impertiente atque inspirante vires, utrum haec tria, mensura, numerus, pondus, in quibus Deum disposuisse omnia scriptum est, erant alicubi antequam crearetur universa natura, an etiam ipsa creata sunt; et si erant antea, ubi erant. Neque enim ante creaturam erat aliquid nisi creator. In ipso ergo

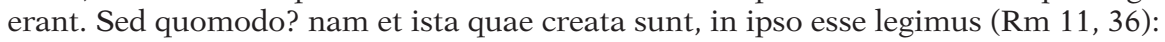
an illa sicut ipse, ista vero sicut in illo a quo reguntur et gubernantur?». 
For Augustine, measure points to how creatures have limit; number enables each creature to find its place in a whole; and weight draws the creature to its purpose. He continues:

«He (God) is surely not identified with these three things as we know them in creatures, the limit in things that we measure, the number in things that we count, the weight in things that we weigh. But in the sense that measure places a limit on everything, number gives everything form, and weight draws each thing to a state of repose and stability, God is identified with these three in a fundamental, true, and unique sense. He limits everything, forms everything, and orders everything ${ }^{61}$.

Augustine points out that even if God is not identical with measure, number, and weight as elements of created reality, they represent the direct impact of God on the world. These three elements of material reality represent the way God acts on creation. As creatures are structured according to measure, number, and weight, they participate in God's trinitarian governance.

For Augustine, God is the «Measure without measure»" ${ }^{62}$. Moreover Augustine does not limit measure only to material things:

«Measure, number, and weight are not to be found or thought of only in stones and wood and other such bodies, earthly or heavenly, having mass or quantity. There is also the measure of an activity, which keeps it from going on without control or beyond bounds... ${ }^{63}$.

61 Ibid. PL 34, 299: «Neque enim Deus mensura est, aut numerus, aut pondus, aut ista omnia. An secundum id quod novimus mensuram in eis quae metimur, et numerum in eis quae numeramus, et pondus in eis quae appendimus, non est Deus ista: secundum id vero quod mensura omni rei modum praefigit, et numerus omni rei speciem praebet, et pondus omnem rem ad quietem ac stabilitatem trahit, ille primitus et veraciter et singulariter ista est, qui terminat omnia et format omnia, et ordinat omnia; nihilque aliud dictum intellegitur, quomodo per cor et linguam humanam potuit: Omnia in mensura, et numero, et pondere disposuisti, nisi: Omnia in te disposuisti?».

62 Augustine, Gn. litt. 4, 3, 8.

63 Augustine, Ibid., 4, 4, 8. PL 34, 299: «Neque enim mensura et numerus et pondus in lapidibus tantummodo et lignis atque eiusmodi molibus, et quantiscumque corporalibus vel terrestribus vel coelestibus animadverti et cogitari potest. Est autem mensura aliquid agendi, ne sit irrevocabilis et immoderata progressio; et est numerus et affectionum animi et virtutum, quo ab stultitiae deformitate, ad sapientiae formam decusque colligitur». 
Augustine refers to human activity which is also governed by limits so that man would not exceed all the natural bounds within which he is created. God has created everything inanimate and rational being within limits of mutable existence for beyond mutability and existence is eternity.

God is the number because in the founding of creation, the Triune God gives unformed matter its shape (form) ${ }^{64}$. So then, every created reality has number formed by «the Number without number» ${ }^{65}$. Material creatures have number in terms of mass and quantity. But men and spiritual beings have «the number of the affections and of the virtues, by which a soul is held away from the unformed formed state of folly and turned towards the form and beauty of wisdom ${ }^{66}$. God is the form and number that keeps spiritual and rational creatures from falling back to an unformed state of folly.

Finally, the Trinity is also the weight of creatures which «draws each thing to a state of repose and stability», so that they would rest in the place for which they were created ${ }^{67}$. Like measure and number, Augustine points out that creaturely weight is «drawn by the Weight without weight ${ }^{68}$. In corporeal realities, weight draws them to find rest in their proper places, like water which seeks its own level and oil which tends to settle in the surface of the water because it is lighter than water in weight. In the moral and spiritual agent, they are drawn by «the weight of the will and of love, wherein appears the worth of everything to be sought, or to be avoided, to be esteemed of greater or less value ${ }^{69}$.

The concept of weight in creatures allows Augustine to make some powerful connection with the use of the metaphor of weight in The Confessions where he famously writes, "My weight is my love. Wherever I am carried, my love is carrying me. By your gift we are set on fire and carried upwards; we grow red hot and ascend $\aleph^{70}$. In this quotation, Augustine associate «weight» with «love» which carries him upward because his heart has been set on fire by God's gift.

\footnotetext{
64 Augustine, Ibid., 1, 4, 9.

65 Augustine, Ibid., 4, 3, 8.

66 Augustine, Ibid., 4, 4, 8.

67 Augustine, Ibid., 4, 3, 7.

68 Augustine, Ibid., 4, 4, 8.

69 Ibid.

70 Augustine, conf. 13, 10.
} 
God then is the one who limits all things, gives intelligible form to all things and directs all things for a purpose. And this threefold principle of measure, number, and weight is also applicable by analogy to spiritual and rational beings as their actions are limited so that they would not go beyond the bounds of their nature (measure), as they possess affections and virtues which keep them from the unformed state of folly and turn towards wisdom (number), and as they are drawn by the weight of the will and of love. Everything then that God creates exhibits this threefold principle which is also the basis of creaturely unity, as Augustine writes:

«There is not a single living creature, after all, in whose body I will not find, when I reflect upon it, that its measures and numbers and order are geared toward a harmonious unity ${ }^{71}$.

Just as the triune God is one and three, so He is the source of creaturely unity through His threeness that is one. And just as every creature is made by the Three who are One, so does every creature mirror the Trinity and His perfect work when it properly exhibits measure, number, and weight as a unified and harmonious whole ${ }^{72}$.

For Augustine it is precisely in the harmony and by being a coherent system that creation shares or participates in the reality of the triune God. And it can't participate in any other way. In Augustine's theological scheme, creation cannot be a «bit» of God nor be an «overflow» of the divine essence because being God is being outside the realm of change and contingency which characterize all creatures ${ }^{73}$.

${ }^{71}$ Augustine, Gn. adu. Man. 1, 16, 26, trans. Edmund Hill. (Brooklyn, NY: New City Press, 2002). PL 34, 185: «Non enim animalis alicuius corpus et membra considero, ubi non mensuras et numeros et ordinem inveniam ad unitatem concordiae pertinere».

72 In reference to Genesis 1, 26ff., Augustine also points out the imprint of the Trinity in the human soul, as it is reflected in the threeness of the mind, the love and the knowledge (Trin. 9, 5, 8; 9, 12, 8); and also, of the memory, the intelligence, and the will (Trin. 10, 11, 18; Conf. 13, 11, 12). Also cf. Luis F. Ladaria, El Dios y Verdadero: El Misterio de la Trinidad (Salamanca: Secretariado Trinitario, 1998), 246-248.

73 Cf. Mark Ellingsen, "Ancient African Insights about Creation and Nature which Relate to Modern Physics: Augustine and Dionysius of Alexandria", Journal of the Interdenominational Theological Center 42 (2016): 63-72. The article deals with the theological and geographical context where the Augustinian thought on creation was conceived and developed. 
Within this theological framework on creation, the view of some modern critics of Augustine who like to see God being «embodied» in the creation or better still, a God who "gives birth» to creation which is «bound in» with God's own being, cannot just fit in ${ }^{74}$. In Augustine's theological scheme, creation tells us most about God when it is most clearly different from Him; it speaks of God's perfection by being imperfect, it shows God's immutability by being changeable. And the more creation shares in the sort of life that God has, the more it steers us back inevitably to their fundamental difference ${ }^{75}$.

The issue of dualism and hierarchy highlighted by Augustine's critics, becomes problematic only within a system where relations of distinct realities ought to be unified and interdependent. But in Augustine's scheme of things, God is not within the same frame of reference with creation. While creation needs God's providence for its existence and sustenance, God in His fullness does not need creation at all ${ }^{76}$. Augustine specifies that creation is purely the result of God's inherent goodness, "for He found His works pleasing, in keeping with the benevolence by which $\mathrm{He}$ was pleased to create them ${ }^{77}$.

It is important to note however that despite the intrinsic difference between God and His creatures, Augustine does not suggest that there exists between them an «unbridgeable separation» or distance, as some of his modern critics have claimed. In fact, in the Literal Meaning of Genesis $(5,20,40)$, Augustine implies the closeness of God with His creation by pointing out the complete ontological dependence of the latter. God for His part acts continuously on creation, preserving its contingent existence:

«Against this opinion we can cite the saying of our Lord, My Father is working Still $(\mathrm{Jn} 5,17)[\ldots]$. Furthermore, God does not make only great and important things but also the lowliest things of this earth.

${ }^{74}$ See the presentation on contemporary critics of Augustine in Part II of this article, 4-9.

75 Cf. Augustine, S. 126, 3. In here, Augustine explains the fundamental difference between the visible creation and the invisible Creator, even if creation somehow reflects the reality of the Creator.

76 Cf. Rowan Williams, On Augustine, 59-78. The insights presented in this book on God's «needlessness» of creation was previously presented in William's article "Good for Nothing? Augustine on Creation", Augustinian Studies 25 (1994): 9-24.

77 Augustine, Gn. litt. 1, 8, 14. 
For St. Paul says: "Foolish man! What you sow does not come to life unless it dies. And what you sow is not the body that is to be but a mere kernel perhaps of wheat or of some other grain. But it is God who gives it a body as He has willed to do, and to each and every seed He gives an appropriate body" (1Cor 15,36-38). Let us, therefore, believe and, if possible, also understand that God is working even now, so that if His action should be withdrawn drawn from His creatures, they would perish ${ }^{78}$.

Clearly for Augustine, the intimacy which exists in the Creator-creature relationship is not only ontological; even after their production from nothing, God continuously desires, sustains, and rules His creation:

«[...] If He who made did not rule the world, what is made would fall to ruin: He cannot but administer that which He hath made. Because then nothing hath been added to the creation, He is said to have rested from all His works; but because He does not cease to govern what He made, rightly did the Lord say, "My Father worketh even hitherto" ${ }^{79}$.

Thus, their value is given not only by being God's good creatures, but in relation to God's unceasing care for every creature by making it, sustaining it, and drawing it to its natural end in God. By citing St. Paul, Augustine stresses the intimacy of every creation to God, not only with the spiritual and rational beings, but even with the most minute of creatures whose existence is also desired and sustained by God ${ }^{80}$.

78 Ibid., 5, 20, 40, trans. John Hammond Taylor: Ancient Christian Writers. Kindle Locations 277-281, (Kindle Edition). PL 34, 335: "Contra quos profertur illa sententia Domini: Pater meus usque nunc operatur... Deinde, quia non solum magna atque praecipua, verum etiam ista terrena et extrema ipse operatur, ita dicit Apostolus: Stulte, tu quod seminas non vivificatur, nisi moriatur; et quod seminas, non corpus quod futurum est seminas, sed nudum granum fere tritici, aut alicuius caeterorum; Deus autem dat illi corpus quomodo voluerit, et unicuique seminum proprium corpus (1 Cor. XV 36-38). Sic ergo credamus, vel, si possumus, etiam intellegamus usque nunc operari Deum, ut si conditis ab eo rebus operatio eius subtrahatur, intercidant».

79 Augustine, S. 68, 5, trans. Edmund Hill. (Brooklyn, NY: New City Press, 1991). PLS 2, 504: «Sed tamen, nisi ille qui fecit, mundum regeret, caderet quod factum est; non potest nisi administrare illud quod fecit. Quia ergo nihil additum est creaturae, requievisse dictus est ab omnibus operibus suis; quia vero quod fecit gubernare non cessat, recte dixit Dominus: Pater meus usque nunc operatur».

80 Cf. Augustine, Vera rel. 18, 35. In here Augustine points out that even the lowest good is from God and is therefore, of God. 
Moreover, God does not create the world by imposing His divine will on «something» because creation for Augustine is production from "nothing ${ }^{81}$. His creative power does not enact over an inert matter; rather it is, in itself, the ground of all power and all agency within creation. God causes an entire process in which intelligible beings come to reality. Creation in Augustine's perspective is the result of God's absolute freedom of self-communication, His willingness to love a complete «other» with absolutely no self-directed interest ${ }^{82}$.

\section{AUGUSTINE'S RELEVANCE TO ECOLOGY}

We have already mentioned that when Augustine wrote his reflections on creation, ecology was not yet a matter of some concern. Yet it doesn't mean that Augustine's doctrine of creation has nothing to contribute to ecology. In fact, despite the criticisms put forward by some of his contemporary critics, we see that Augustine's theology of creation is not one-sided. His outlook of creation contains positive resources for developing certain perspective which may inspire positive response to John Paul II's call for «ecological conversion» in the modern times ${ }^{83}$.

In this final part of the article, we try to highlight just some of the prominent doctrines of Augustine which might be understood to contribute positively to the contemporary ecological concerns.

\subsection{Fundamental Goodness and InterRelatedness of Creation}

Contrary to the common presumption of the Augustinian pessimism towards the material universe, Augustine has a very clear, optimistic, and inspiring outlook of the created world. In fact, in Sermon 68, while reflecting on the beauty of nature he said:

${ }^{81}$ On creation from nothing in Augustine's thought, confer Tarsicius van Bavel, "The Creator and the Integrity of Creation in the Fathers of the Church, Especially in Saint Augustine", Augustinian Studies 21 (1990), 4-7.

82 Cf. Augustine, Gn. adu. Man. 1, 2, 4: In here, Augustine stresses that God creates not out of need but out of love.

83 Cf. Catechesis (17 January 2011), 4: Insegnamenti 41/1 (2011), 179. 
«Observe the beauty of the world and praise the plan of the creator. Observe what he made, love the One who made it [...] because He also made you, His lover, in His own image» ${ }^{84}$.

For Augustine, creation reflects God's beauty and goodness, and for rational creatures like man, it serves as a mirror which reflects his own goodness, being created to God's image and likeness must lead the whole of humanity to the worship and enjoyment of God. In a masterly usage of a metaphor, Augustine likens creation to an «open book, not written by ink»:

«Others, in order to find God, will read a book. Well, as a matter of fact there is a certain great book, the book of created nature. Look carefully at it top and bottom, observe it, read it. God did not make letters of ink for you to recognize Him in; He set before your eyes all these things He has made. Why look for a louder voice? Heaven and earth cry out to you, "God made me" [...]. Observe heaven and earth in a religious spirit $[\ldots]{ }^{85}$.

Struck by how a diverse universe in motion, holds together in an orchestrated harmony, Augustine used an imagery of a «big book» that brings a story-like quality to how he sees the world. Augustine's trinitarian interpretation of creation enables him to see the world as a unified whole whose status in the eyes of God is "good» with regard to individual creature; and «very good» with reference to the whole created universe. If for Augustine nature is indeed like a book that tells us about God, then we need to learn how to read it from «top to bottom». We can see who the subject is in their story and enjoy that story in all its goodness because of its author:

"All whatsoever the Lord willed, He made in the heaven, and in the earth, in the sea, and in all its deep places (Psalm 134:6). Who

${ }^{84}$ Augustine, S. 68, 5, trans. Edmund Hill. (Brooklyn, NY: New City Press, 1991). PLS 2, 504: «Tu autem non valde cures, si gyros siderum et caelestium terrenorumve corporum ignores: vide pulchritudinem mundi, et lauda consilium Creatoris: vide quod fecit, ama qui fecit. Tene hoc maxime, ama qui fecit; quia et te ipsum amatorem suum ad imaginem suam fecit».

${ }_{85}$ Augustine, S. 68, 6, trans. Edmund Hill. (Brooklyn, NY: New City Press, 1991) PLS 2, 505: «Alius, ut inveniat Deum, librum legit. Est quidam magnus liber ipsa species creaturae: superiorem et inferiorem contuere, attende, lege. Non Deus, unde eum cognosceres, de atramento litteras fecit: ante oculos tuos posuit haec ipsa quae fecit. Quid quaeris maiorem vocem? Clamat ad te caelum et terra: Deus me fecit». 
can comprehend these things? Who can enumerate the works of the Lord in the heaven and earth, in the sea, and in all deep places? Yet if we cannot comprehend them all, we should believe and hold them without question, because whatever creature is in heaven, whatever is in earth, whatever is in the sea and in all deep places, has been made by the Lord $[\ldots]{ }^{86}$.

The Augustinian perspective of the created universe reminds us of how God Himself cares and loves creation. Creation is the result of God's love, pouring "out of the largeness of His bounty» (abundantiam beneficentiae $)^{87}$. God's trinitarian love which is generated by the clinging of the Three Persons to each other in eternity, overflows towards creation by the actions of the Father, Son, and Holy Spirit in the world. It is so that while the world is not God, it is saturated by the dynamism of the Trinitarian love.

While Augustine's view of the world is not egalitarian, i.e., he recognizes the hierarchy of creatures, he does have a conception of the equality of creatures with respect to their origin. There is indeed a "hierarchy» based on the amount of perfections every creature receives from God. But in relation to their origin, all creatures are equal because they all receive their being from God and manifest it in varied ways according to the condition of their existence ${ }^{88}$. The inanimate creatures participate in the divine dynamism through their own movements, limited and guided by measure, number, and weight; while the human subjects participate by their natural orientation towards God through their own limited but rational nature (measure), affections and virtues which lead them towards wisdom (number), and the capacity to love which is the weight that finds rest in $\operatorname{God}^{89}$.

How does this relate then to contemporary ecological concerns?

Everything in this universe has its own place in the divine ordering of things and its own story in the «big book» of nature. Nothing

86 Augustine, en. Ps. 134, 6. PL 36, 1745: «Omnia quaecumque voluit, Dominus fecit in coelo et in terra, in mari et in omnibus abyssis. Quis autem comprehendat haec? quis enumeret opera Domini in coelo et in terra, in mari et in omnibus abyssis? Tamen si comprehendere omnia non possumus, inconcusse credere et tenere debemus quoniam quidquid creaturarum in coelo, quidquid in terra, quidquid in mari et in omnibus abyssis a Domino factum est [...]».

87 Augustine, Gn. litt. 1, 7, 13.

88 Cf. Augustine, ep. 140, 2, 3.

89 Cf. Augustine, Gn. litt. 4, 3, 7. 
is superfluous. This doctrine is in line with Pope Francis's view as he claims «that each creature has its own purpose in God's eternal design. The entire material universe speaks of God's love ${ }^{90}$. Augustine's doctrine which recognizes the goodness of every creature and draws a clear picture of the interrelatedness of creation, highlights the fact that every decision we make can cause reverberations throughout an ecosystem. Everything is part of God's good creative work, and therefore is connected by a common origin and end in God. This theological interpretation of Augustine can certainly inspire us to reflect on our own place in the universe and reevaluate the impact of our own actions on the environment. If nature is indeed a "great book" wide open for everybody to read, then we need to learn how to read it rightly. And for Augustine, the right reading of this book must lead us to know God because creation tells us of her creator, not by ink and paper, but by the grandeur of her beauty and the immensity of her design.

\subsection{Image of God and Human Dominion}

Some critics of Augustine have accused him of having portrayed an image of God who created the universe by arbitrary will ${ }^{91}$. But by looking directly into his writings, we also see that such accusation does not really measure up to Augustine's true doctrine. For Augustine, "God is all-powerful not by arbitrary power but by the strength of wisdom ${ }^{92}$. Thus God's action which brings creation to existence proceeds purely from His wisdom and divine goodness. In response to the act of God, animate and inanimate things shape themselves as a balance whole, seeking all the time what science calls dynamic equilibrium.

But all this is simply the result of the divine wisdom and goodness that is not conditioned by any need or necessity. Roman Williams points out that in Augustine's theological scheme, creation is viewed as a product of God's pure desire for the good of another; that from God's «point of view», creation is "good for nothing» as it doesn't serve a divine need ${ }^{93}$. God creates from the bounty of His goodness and in His

\footnotetext{
$90 \quad$ Pope Francis, Laudato si', 84.

91 See Colin Gunton, The Triune Creator: A Historical and Systematic Study, 75-76.

92 Augustine, Gn. litt. 9, 17, 32.

93 Cf. Rowan Williams, On Augustine, 72-73.
} 
divine wisdom governs creation with love that «seeks nothing for itself but the joy of the other ${ }^{94}$. This is the image of God that Augustine portrays in his doctrine of Trinity and creation.

Now for Augustine, the work of human dominion over nature is what makes humanity distinct from among other created beings. Basing his reflection on Genesis 1:26, Augustine argues that God has granted to humanity the dominion over creatures. He understands dominion as the rule by human beings of nonhuman creatures through the exercise of reason. The danger of the concept of dominion from an ecological perspective is identifying dominion with the domination of human reason over the world, the license to exercise arbitrary will without restraint. History has stigmatized humanity of abusive kings or political leaders who ruled by arbitrary will, politically motivated ideologies charged with greed and self-vested interest, and the rhetoric of modern science which promises to conquer the world by discovering its mysteries and exposing its secrets.

But this is not the kind of dominion which Augustine teaches in his Trinitarian view of creation. For Augustine dominion must reflect the human vocation of being the image of God in the world: "What gives him authority? The image of God $»^{95}$. Then he continued what this image of God means: «We have existence in common with stick and stones, life in common with trees, sense in common with beasts, understanding in common with angels ${ }^{96}$. Human being is special and, in a sense, different from other creatures because of his rationality. The image of God in human being lies in his exercise of reason. And it is the right exercise of reason that gives him authority or dominion over other inferior creatures ${ }^{97}$.

\footnotetext{
$94 \quad$ Ibid., 75.

95 Augustine, S. 43, 3. (trans. Edmund Hill. Brooklyn, NY: New City Press, 1991). PL 38, 255: «Unde habeat potestatem? Propter imaginem Dei».

96 Ibid. s. 43, 4. PL 38, 255: «Habemus ergo, ut cuncta breviter retexamus, ipsum esse cum lignis et lapidibus, vivere cum arboribus, sentire cum bestiis, intellegere cum angelis».

${ }_{97}$ A more comprehensive discussion on man as a special creature being created in the image and likeness of God is tackled by Ma. Carmen Dolby Múgica's book: El Hombre es Imagen de Dios. Visión Antropológica de San Agustín, (Eunsa, Pamplona 2002).
} 
Furthermore, to be the image of God, for Augustine, is to seek out God and to cling to Him in the Son and the Holy Spirit, in the particular way that God has made humanity ${ }^{98}$. All human works over creation must be done in reference to God. Dominion as a reflection of the image of God is the rule of the generosity of love which does not seek its own interest and makes it possible for others to know the love of God.

Keeping in mind Augustine's understanding of God's creative work, the dominion of the land or animals can be viewed as the exercise of human reason not merely in terms of their utility, but with respect to the love of the creature as God's creation and thereby leads one to praise and love God as the creator. If human domination of the land and animals instead destroys creation and cause unnecessary harm to the world, then for Augustine, it can hardly be called dominion at all. For God did not create the world to enjoy its destruction and to delight in its abuse.

\subsection{Uti et FRUi}

Augustine sees the order and beauty of the world as an order of love, ordo amoris: "All natures, then, in as much as they are, and have therefore a rank and species of their own, and a kind of internal harmony, are certainly good $»^{99}$. The diversity of material and spiritual things is divinely intended, and inherently good. But humans have a unique status that derives from creativity, intelligence and self-transcendence.

By reflecting on the natural order established by God in creation, Augustine developed a classic doctrine of uti et frui -the use and fruition of creation by man ${ }^{100}$. In his work On Christian Doctrine, Augustine distinguishes "fruition», which is directed towards the thing itself as the source of love, from «using», which recognizes a thing, not as the source of love in itself, but points beyond itself to another love:

\footnotetext{
98 Augustine, Gn. litt. inp. 16, 59, trans. Edmund Hill (Brooklyn, NY: New City Press, 2002). CSEL 28, 1, 499/15-21.

${ }_{99}$ Augustine, Ciu. 12, 5, trans. Marcus Dods, in Nicene and Post-Nicene Fathers, First Series, vol. 2, ed. Philip Schaff. (Buffalo, NY: Christian Literature Publishing Co., 1887). CCL 48, 359/1-4.

100 A treatment of Augustine's classic doctrine of uti et frui can also be found in Andrew Brian McGowan's “To Use and Enjoy: Augustine and Ecology", St. Mark's Review 212 (May 2010): 89-99.
} 
«For to enjoy a thing is to rest with satisfaction in it for its own sake. To use, on the other hand, is to employ whatever means are at one's disposal to obtain what one desires, if it is a proper object of desire; for an unlawful use ought rather to be called an abuse» ${ }^{101}$.

Augustine teaches that earthly things are meant to be «used» by man because of the inherent goodness that God has endowed them with, but the «fruition or enjoyment» of all things must lead man to the Creator Himself who is the source of all goodness and the proper object of man's desire. If this order of use and fruition is altered and creatures are enjoyed for their own sake without reference to the Creator, for Augustine it is a form of «abuse». Augustine identifies God and He alone as the ultimate and proper object of man's enjoyment. Other things are available for "proper use».

In the Trinity, Augustine explains how a superior creature can «use» the inferior ones but must «enjoy» its coequal and that which is superior to it. Concretely, he refers to the fact that being human, i.e. endowed with reason, man can use nonrational creatures for his own needs, may enjoy other human beings like himself, but must encounter always the fullness of happiness in God alone. And if this order of things is reversed, man can be enslaved by temporal things; he is not anymore, a steward of creation but its slave:

"When, therefore, the creature is either equal to us or inferior, we must use the inferior in order to God, but we must enjoy the equal duly in God. For as you ought to enjoy yourself, not in yourself, but in Him who made you, so also him whom you love as yourself. Let us enjoy, therefore, both ourselves and our brethren in the Lord; and hence let us not dare to yield, and as it were to relax, ourselves to ourselves in the direction downwards» ${ }^{102}$.

101 Augustine, Doctr. chr. 1, 4, 4, trans. J. F. Shaw, in Nicene and Post-Nicene Fathers, First Series, vol. 2, ed. Philip Schaff (Buffalo, NY: Christian Literature Publishing Co., 1887), Simonetti 22/1-4: «Frui est enim amore inhaerere alicui rei propter seipsam. Uti autem, quod in usum venerit ad id quod amas obtinendum referre, si tamen amandum est. Nam usus illicitus abusus potius vel abusio nominandus est».

102 Augustine, Trin. 9, 8, 13, trans. Arthur West Haddan, in Nicene and Post-Nicene Fathers, First Series, vol. 3, ed. Philip Schaff. (Buffalo, NY: Christian Literature Publishing Co., 1887). PL 42, 968: "Cum ergo aut par nobis, aut inferior creatura sit, inferiore utendum est ad Deum; pari autem fruendum, sed in Deo. Sicut enim te ipso, non in te ipso frui debes, sed in eo qui fecit te; sic etiam illo quem diligis tamquam te ipsum. Et nobis ergo et fratribus in Domino fruamur, et inde nos nec ad nosmetipsos remittere, et quasi relaxare deorsum versus audeamus». 
Augustine teaches that proper use is not merely conformity to rules, but the celebratory engagement with other humans that arises from shared participation in the ordo amoris. The things thus used are neither neutrally good and hence to be exploited, nor ultimate ends and therefore to be worshipped, but must be approached in relation to their and our highest end, who is of course also their and our origin -God.

However, according to Augustine, because of sin, man's ability to understand the purpose of God's creation has been blurred: «But perhaps the slow hearts of some of you cannot yet receive that light, because they are burdened by their sins, so that they cannot see» ${ }^{103}$. For Augustine, sin not only disrupts the order of the world and the harmony among creatures, so that it tends towards nothingness, but also distorts man's ability to see how creation exists in God, just like a blind man standing in the sunlight but is absent from the light because of the lack of eyesight. Pride, sin, and selfishness cause man to turn his back to God, distance himself from other beings equal to him, and enclose himself within himself, thus leading him to alter the ordo amoris, abuse and exploit selfishly creation, and create chaos in world ${ }^{104}$.

The major cause of much of the ecological trouble we face today is the human use of the world without respect for the complex natural relationships by which it has been composed and the balance that it exhibits. In some respects that use could be described as covetousness and greedy, perhaps even an addiction to consumption without boundaries. This may be an example of using something because it pleases man, finding ultimate love in himself. If this happens, man does not anymore act as steward of creation but its proprietor who lords over and exploits creation unto disorder and destruction.

In the mind of Augustine, man is just part of God's creation, but among all creatures he has the vocation to love others and to love God above all things. The ordo amoris which regulates the relationship among creatures, and between the creatures and the Creator dictates that it is necessary to love the Creator for being the Highest Good, and not to love creation independently of its Creator. In accordance to this principle, the right use of the created things must lead man to love God and give Him

${ }_{103}$ Augustine, Io. eu. tr. 1, 19, 1. PL 35, 1388: «Sed forte stulta corda adhuc capere istam lucem non possunt, quia peccatis suis aggravantur, ut eam videre non possint».

104 Cf. Augustine, Gn. litt. inp. 1, 3. 
the praise and glory He deserves, as St. Augustine points out in the exposition of the Psalm $(144,4)$ :

«For how great things besides has His boundless Goodness and illimitable Greatness made, which we do not know! When we lift the gaze of our eyes even to the heaven, and then recall it from sun, moon, and stars to the earth, and there is all this space where our sight can wander; beyond the heavens who can extend the eyesight of his mind, not to say of his flesh? So far then as His works are known to us, "let us praise Him through His works" (Romans 1:20). "Generation and generation shall praise Your works" (Psalm 144:4). Every generation shall praise Your works» ${ }^{105}$.

God's command to subdue the earth is a call to use creation according to the ordo amoris, not to exploit it. Our failure in our dealings with one another and with creation, and with God, may have resulted from the confusion or substitution of what is to be used with what is to be enjoyed. In making ourselves gods over creation, we abuse God, ourselves, and the world whose care is our vocation. If we make created things our gods, paradoxically we pursue wealth in such a way that abuses creation, rather than serving or sustaining it.

\section{CONCLUSION}

In Laudato si' when Pope Francis admonishes that in relation to contemporary ecological crisis, "there is a need to take into consideration deeper and transcendental questions» ${ }^{106}$, he hinted that the question of ecology is not only a matter of external and environmental issues, it is above all an interior matter -the ecology of the human soul. This is well within the spirit of Pope John Paul II's vision, who, by pointing sharp-

105 Augustine, En. Ps. 144, 4. PL 36, 1872: «Illius enim immensa bonitas et interminabilis magnitudo, quanta alia fecit quae nos non novimus? Quando quidem aciem oculorum nostrorum usque ad coelum extendimus, et a sole et a luna et a stellis rursus revocamus ad terram; et hoc totum spatium est ubi vagatur acies nostra: ultra coelos quis extendat vel aciem mentis, non dicam carnis? Ergo quantum nota sunt nobis opera eius, laudemus eum per opera eius. Invisibilia enim eius, a constitutione mundi, per ea quae facta sunt intellecta conspiciuntur. Generatio et generatio laudabit opera tua. Omnis generatio laudabit opera tua».

106 Cf. Pope Francis, Laudato si', 160. 
ly to consumerism and man's failure to look at natural environment far more than its utility as the main culprit, calls for the so-called «ecological conversion» ${ }^{107}$.

Even if during the time of Augustine, the ecological sensitivity which we know today didn't exist, his thoughts on creation are extremely rich and seemingly «futuristic» that today they can effectively help us understand and discover essential aspects of the universe leading us to reflect with greater profundity on the ecological crisis we face in the present.

One of the important things we have seen in the writings of Augustine is that his thoughts on creation are heavily founded on the Word of God. Augustine's in-depth reflection on the scriptural story of creation, enabled him to draw a clear picture of the creator as a Triune God whose impact on creation reflects the concrete works of the three divine Persons in the world, of what place and relation man must have with other creatures, and of the fact that the whole of creation has a common orientation towards the fullness of peace and perfection God has designed in all eternity.

On the other hand, the created world for Augustine is like an open book which tells the story of God's beauty and greatness. It is a book which everybody can read because it is not written with ink and paper, but with living and nonliving, tangible realities which don't cease proclaiming and praising the greatness of their maker. In this Augustinian perfective, the care of nature does not only have a practical and material purpose of satisfying man's need in the present and for the future, but also above all because the entire universe has a sacred value - it is a form of sacrament that signifies the presence of God and invites us to raise our eyes and hearts to the transcendent truth so that we may not remain locked in the material goods of this earth.

Moreover, creation according to Augustine, does not only speak of God through its beauty and harmony. His reflection on Wisdom 11:20 enabled him to conceive how creatures have intrinsic value in themselves as they participate in the divine reality through their measure, number, and weight, thus making them a concrete testimony of God, who is in Himself, a Trinity. Thus, every creature regardless of its usefulness, size, and perfection, is not superfluous and is worthy of respect and care for it has its origin from God, somehow bears the reflection and vestiges of the creator, and is continuously desired and sustained by God.

107 Cf. John Paul II, Redemptor Hominis, 287. 
Finally, in Augustine's doctrine of creation, we are reminded of our special place and what role we must play in the created world. For Augustine, man is the steward of creation -not its owner- because it was God who created and put all things at his service. As steward, gifted with creativity, intelligence and self-transcendence, man has a sublime responsibility to care and guide creation, so that they may remain fruitful and faithful to their ordained purpose; and most importantly, that they may continue to be a sign of God, who created them not out of necessity, but by the outpouring of «the largeness of His bounty» (abundantiam beneficentiae $)^{108}$. Hence, creation must not be exploited for selfish and self-centered interest, but must be used moderately and rationally (uti), and that only in view of man's love for God that it must be enjoyed (frui).

In this theological scheme of Augustine, we may conclude that «ecological conversion» is first and foremost, a «conversion of the heart» as we reflect on nature and our place in it: "Observe the beauty of the world and praise the plan of the creator. Observe what he made, love the One who made it $[\ldots]$ because $\mathrm{He}$ also made you, His lover, in His own image ${ }^{109}$.

\section{ABBREVIATIONS OF THE WORKS OF ST. AUGUSTINE (AUGUSTINUS LEXIKON)}

Ciu. De ciuitate Dei (The City of God).

Conf. Confessionum (The Confessions)

Doctr. chr. De Doctrina Christiana (The Christian Doctrine).

En. Ps. Enarrationes in Psalmos (The Commentary of the Psalms).

Ep. Epistulae (The Letters)

Gn. adu. Man. De Genesi adversus Manicheos (Commentary to the Genesis against the Manicheans).

Gn. litt. De Genesi ad Litteram (Litteral Commentary to the Genesis).

Gn. litt. inp. De Genesi ad Litteram inperfectus (Unfinished Litteral Commentary to the Genesis).

Io. eu. tr. In Iohannis Euangelium Tractatus (The Commentary to the Gospel of John).

S. Sermones (Sermons).

\footnotetext{
108 Augustine, Gn. litt. 1, 7, 13.

109 Augustine, S. 68, 5.
} 
Trin. De Trinitate (The Trinity).

Vera rel. De Vera Religione (The True Religion).

\section{REFERENCES}

\section{Latin TeXt Sources}

Patrologiae Cursus Completus. Series Latina. Paris, 1844-64.

Patrologiae Latinae Supplementum. Series Latina. Belgium: Brepols, 1900. Corpus Christianorum. Series Latina. Tournhout: Brepols,1953-.

Corpus Scriptorum Ecclesiasticorum Latinorum. Wien: Österrichische Akademie des Wisenschaften, 1866-.

Translations of the Works of Augustine

Augustine. City of God. Translated by Marcus Dods. Nicene and Post-Nicene Fathers, First Series, vol. 2, ed. Philip Schaff. Buffalo, NY: Christian Literature Publishing Co., 1887.

Augustine. Letters. Translated by R. J. Teske. Brooklyn, NY: New City Press, 2003.

Augustine. On Christian Doctrine. Translated by J. F. Shaw. Nicene and Post-Nicene Fathers, First Series, vol. 2, edited by Philip Schaff. Buffalo, NY: Christian Literature Publishing Co., 1887.

Augustine. On Genesis: A Refutation of the Manichees. Translated by Edmund Hill. Brooklyn, NY: New City Press, 2002.

Augustine. Sermons. Translated by Edmund Hill. Brooklyn, NY: New City Press, 1991.

Augustine. The Literal Meaning of Genesis. Translated by John Hammond Taylor. Ancient Christian Writers. Kindle Locations 277-281, Kindle Edition.

Augustine. The Literal Meaning of Genesis: An Unfinished Book. Translated by J. H. Taylor, S.J. Newman Press, New York, 1982.

Augustine. The Trinity. Translated by Arthur West Haddan. Nicene and Post-Nicene Fathers, First Series, vol. 3, edited by Philip Schaff. Buffalo, NY: Christian Literature Publishing Co., 1887.

Augustine. Unfinished Literal Commentary on Genesis. On Genesis. Translated by Edmund Hill. Brooklyn, NY: New City Press, 2002. 
MARK ROCHELLE FERRAREN, CONTEMPORARY ECOLOGY AND AUGUSTINE 401

\section{Catholic/Theological Sources}

Benedict XVI. Address to the clergy of the Diocese of Bolzano-Bressanone (6 August 208). Acta Apostolicae Sedis 100 (2018).

John Paul II. Catechesis (17 January 2011). Insegnamenti 41/1 (2011).

John Paul II. Encyclical Letter Redemptor Hominis (4 March 1979). Acta Apostolicae Sedis 71 (1979).

Pope Francis. Encyclical Letter Laudato si' (4 September 2015). Acta Apostolicae Sedis 107 (2015).

Pope Paul VI. Apostolic letter Octogesims Adveniens (14 May 1971). Acta Apostolicae Sedis 63 (1971).

The Catholic Bishops' Conference of the Philippines. A Pastoral Letter on Ecology: What is happening to our beautiful land. Manila: The Catholic Bishops' Conference of the Philippines, 1988.

\section{Books of SeCondary Authors}

Dunham, Scott A. The Trinity and Creation in Augustine. Albany: State University of New York Press, 2018.

Green, Bradley G. Colin Gunton and the Failure of Augustine: The Theology of Colin Gunton in Light of Augustine. Oregon: Pickwick Publications, 2011. https://doi.org/10.5840/augstudies201142243

Gunton, Colin. "Between Allegory and Myth: The Legacy of the Spiritualizing of Genesis". In The Doctrine of Creation, edited by C. Gunton, 47-62. Edinburgh: T. and T. Clark, 1997.

-. Promise of Trinitarian Theology. Edinburgh: T. and T. Clark, 1991.

-. The One, the Three and the Many: God, Creation and the Culture of Modernity. Cambridge: Cambridge University Press, 1993.

-. Triune Creator: A Historical and Systematic Study. Grand Rapids, MI: Eerdmans, 1998.

Jenson, Robert. The Triune Identity. Philadelphia: Fortress Press, 1982.

Ladaria, Luis F. El Dios y Verdadero: El Misterio de la Trinidad. Salamanca: Secretariado Trinitario, 1998.

Lydon, Juan J., Joaquín García y Roberto Jaramillo. Ecoteología. Una perspectiva desde San Agustín. Actas del IV Simposio sobre la relectura del pensamiento de San Agustín desde América Latina. México: OALA, 1996.

Marsh, Thomas. The Triune God. New London, CT: Twenty-third Publications, 1994. 
McFague, Sallie. Models of God: Theology for an Ecological Nuclear Age. London: SCM, 1987.

Múgica, Maria del Carmen Dolby. El hombre es imagen de Dios. Visión Antropológica de San Agustín. Pamplona: Eunsa, 2002.

Pagels, Elaine. Adam, Eve and the Serpent. London: Penguin Books, 1988.

Primavesi, Anne. From Apocalypse to Genesis: Ecology, Feminism and Christianity. London: Burns \& Oates, 1991.

Rist, John M. Augustine: Ancient Thought Baptized. Cambridge: Cambridge University Press, 1994. https://doi.org/10.1017/s0034412500023945

Ruether, Rosemary R. Gaia and God: An Ecofeminist Theology of Earth Healing. San Francisco, CA: Harper Collins, 1992.

Williams, Rowan. On Augustine. New York: Bloomsbury Publishing, 2016.

MagaZine AND Journal

Arranz Rodrigo, Marceliano. "Fuentes de la doctrina agustiniana de la creación virtual". Estudio Agustiniano 23 (1988): 153-166.

—. "Semillas de futuro. Anotaciones a la teoría agustiniana de la creación virtual”. Cuadernos Salmantinos de Filosofía 23 (1987): 43-77.

—. "Semillas de futuro. Anotaciones a la teoría agustiniana de la creación virtual”. Cuadernos Salmantinos de Filosofía 13 (1986): 35-60.

Ellingsen, Mark. "Ancient African Insights about Creation and Nature which Relate to Modern Physics: Augustine and Dionysius of Alexandria". The Journal of the Interdenominational Theological Center 42 (2016): 63-72.

McGowan. "To Use and to Enjoy: Augustine and Ecology". St Mark's Review 212 (2010): 89-99.

Muller Earl. "The Dynamic of Augustine's De Trinitate: A Response to a Recent Characterization". Augustinian Studies 26 (1995): 65-91. https://doi.org/10.5840/augstudies19952613

Tejerina, Cándido. "Creación y caída en los libros XI-XIV de La ciudad de Dios". Estudio Agustiniano 5 (1970): 239-296.

Van Bavel, Tarsicius. "The Creator and the Integrity of Creation in the Fathers of the Church, especially in Saint Augustine". Augustinian Studies 21 (1990): 1-33. https://doi.org/10.5840/augstudies1990214

Williams, Rowan. "Good for Nothing? Augustine on Creation". Augustinian Studies 25 (1994): 9-24. https://doi.org/10.5840/augstudies1994257

Yardley, Jim and Laurie Goodstein, "Pope Francis, in Sweeping Encyclical, Calls for Swift Action on Climate Change". The New York Times (18 June 2015): A6. 